\title{
Fungal Ecology Special Issue: Editorial
}

\author{
Franck Carbonero $^{1} \cdot$ Gary Strobel $^{2}$
}

Published online: 3 June 2021

(c) The Author(s), under exclusive licence to Springer Science+Business Media, LLC, part of Springer Nature 2021

Fungal ecology stands in a peculiar niche between microbial and community ecology. With the booming popularity of microbiome and other omics technologies, bacteria have increased their dominance in the microbial ecology field [1, 2], while traditional ecologists continue to favor plant and to some extent animal models [3-5]. It thus appears that fungi and other unicellular eukaryotes (UE) have been left in the ever-widening discipline schism. This is not to say that interest in fungal ecology is fading, but that the current literature is a lot more disparate in terms of approaches and techniques used. The ultimate driving force moving fungal ecology forward is the need to understand all of the forces of nature that support and sustain life.

Fungi and UE continue to present significant challenges for taxonomic and phylogenetic identification [6]. A major underlying need of fungal ecology is to have a strong base of taxonomy and this has certainly come with all the advances made in nucleic acid sequence technology. In fact, some researchers have put too much reliance on these techniques to the complete exclusion of employing classical methods in fungal isolation and characterization. While bacterial microbiome studies enjoy relatively reliable taxonomic identification from 16S rDNA gene and even metagenomic sequencing, mycobiome studies remain few and far between, with limited taxonomy solving power. Indeed, phenotypic and culture-based studies remain an invaluable tool for fungal biology and ecology [7]. Of course, the advantage of having these organisms in pure culture is that they can be handled and studied in virtually all aspects of their biology which, in fact, may help in understanding how they function in their natural ecological settings. Thus, many challenges remain in examining the hundreds of niches of the planet where

Franck Carbonero

franck.carbonero@wsu.edu

1 Department of Nutrition and Exercise Physiology, Elson Floyd School of Medicine, Washington State UniversitySpokane, Spokane, WA 99202, USA

2 Department of Plant Sciences, Montana State University, Bozeman, MT 59717, USA fungi may have taken up residence, not only in demonstrating their existence in these niches but trying to have them in pure culture and appropriately stored for further study. Of note, fungi and UE have not been popular models to test ecological theories. This is due to their small size, disparate distribution, metabolism, and technical challenges for controlled experiments.

It is also likely that fungal ecology needs to stay between these two general fields because fungi and UE are important for reasons that are shared between these two research fields:

- Fungi directly and indirectly participate in feeding us.

- Fungi and UE are crucial drivers of soil and plant health.

- Fungi and UE are implicated in fermentation and nutrient cycling in all ecosystems.

- Fungi and UE can cause spoilage and diseases.

The diversity and distribution of fungi continues to be explored in environments from soil $[8,9]$ to freshwater [10] and our oceans [11]. Specific emphasis continues to be given to plant-fungal interaction, especially mycorrhizae [12-16]. Other symbiotic or non-symbiotic interactions are increasingly studied [17], with the "zombie ants" disease caused by Ophiocordyceps unilateralis being an extremely popular example [18].

Just as important in understanding the ecology of any organism is how it is able to function in the niches that it occupies. Significant research and development efforts are directed to the continued improvement of yeasts for food fermentation [19], in particular bread and wine making [20-23].

With this approach may come the discovery of new and totally unexpected fungi and their corresponding natural products. As an example, it is now known that plants have a microbiome, but the flora of this biome largely consists of various fungal species [24, 25]. Only a small portion of the 350,000 plant species that exist have been examined for the constituents of their biome [26-28]. And in fact, only a handful of species have ever been examined for their complete microbiome which consists of the entire make-up of 
the plant including roots, shoots, leaves, flowers, and fruits, and the network of relationships between these different compartments' microbiome has only begun to be unraveled [29]. A closer look at one fungal endophytic species, Ascocoryne sarcoides, revealed that it produces hydrocarbons that have biofuel potential and the completed genomic analysis of this organism represents a first for fungal endophytes [30]. Other endophytes have been examined for their fuel potential and it seems to be a promising area of research with enormous potential for helping to solve issues related to our need for liquid fuel and an ever increasing need to reduce carbon dioxide in the atmosphere [31,32]. Thus, the broad approach of fungal ecology should represent efforts to understand how the organism is able to live in its environment, which may lead to completely unexpected results that have wide ranging implications and applications.

This special issue compiles recent findings in several areas of research, starting with endophytes. Saxena et al. provide a review of the ecological and potential industrial and agronomic use of members of the genus Muscodor [33]. Oita et al. report that endophyte diversity is likely best assessed by combining culture and high-throughput sequencing [34]. Bao et al. describe host-dependent response to endophyte colonization towards grass parasitism [35]. Xie et al. report on the beneficial impact on peanut soil parameters from Phomopsis liquidambaris inoculation [36]. Finally, Win et al. report plot-to-plot variation in tea plant-associated endophytes, but no significant impact of pesticides [37].

In keeping with the role of fungi in agricultural ecosystems, several papers address ecology and distribution in different cultures. Cureau et al. provide extensive surveys of the fungal diversity in soil, leaves, and grapes from a range of locations, varieties, and growth years for table and wine grapes grown in a distinct agricultural area in the Southern US [38]. Shi et al. report spatiotemporal differences in dynamics and composition of the fungal rhizosphere in cotton fields from arid Northwest China [39].

Next, several articles focus on different aspects of mycorrhizal and soil fungal ecology. Ferreira et al. report results from microcosm experiments supporting a model where soil microbial diversity modulates the plants' root colonization by arbuscular mycorrhizal fungi (AMF) [40]. Dos Passos et al. report diversity and composition of AMF in the Brazilian dry forest and describe several geological and plant host drivers [41]. Rodrigues et al. studied the diversity of AMF in a Brazilian conservation unit of Atlantic forest areas and report that natural regeneration increased AMF diversity [42]. Birhane et al. report on the diversity of AMF in fragmented natural forest remnants (Birhane et al., 2021). Kellog et al. tested the ability of quinoa to form AMF symbiosis and report limited association between $\mathrm{AMF}$ and roots [43]. Romero-Olivares conducted an in silico analysis to associate several terrestrial nutrient cycle traits with fungal genes [44]. And finally, Pereira et al. describe the effect of Acacia invasion in deciduous forests on the microbial litter decomposition.

The fungal diversity in unusual hosts and environments remains a popular topic. Ogaki et al. describe the fungal diversity of sediments from deep-sea [45] and Rosa et al. describe airborne fungal diversity [46] using metabarcoding. Pino-bodas et al. report a survey of the Cladonia photobiont global biodiversity [47]. Morrison et al. describe the composition and potential metabolic roles of bacterial and fungal communities in tropical peatlands [48]. Huang et al. describe a correlation between soil fungal diversity and dissolved organic matter in semi-arid regions [49]. Borruso et al. describe the association between soil composition and Indri lemur gut mycobiota, highlighting the importance of geophagy in lemur digestive processes [50].

\section{References}

1. Enaud R, Vandenborght L-E, Coron N, et al (2018) The mycobiome: a neglected component in the microbiota-gut-brain axis. Microorganisms 6. https://doi.org/10.3390/microorganisms6 010022

2. Galloway-Peña JR, Kontoyiannis DP (2020) The gut mycobiome: the overlooked constituent of clinical outcomes and treatment complications in patients with cancer and other immunosuppressive conditions. PLoS Pathog 16:e1008353. https://doi.org/10. 1371/journal.ppat.1008353

3. Kissling WD, Walls R, Bowser A et al (2018) Towards global data products of Essential Biodiversity Variables on species traits. Nat Ecol Evol 2:1531-1540. https://doi.org/10.1038/ s41559-018-0667-3

4. Bonal D, Burban B, Stahl C et al (2016) The response of tropical rainforests to drought-lessons from recent research and future prospects. Ann For Sci 73:27-44. https://doi.org/10.1007/ s13595-015-0522-5

5. Laughlin DC, Gremer JR, Adler PB et al (2020) The net effect of functional traits on fitness. Trends Ecol Evol 35:1037-1047. https://doi.org/10.1016/j.tree.2020.07.010

6. James TY, Stajich JE, Hittinger CT, Rokas A (2020) Toward a fully resolved fungal tree of life. Ann Rev Microbiol 74. https:// doi.org/10.1146/annurev-micro-022020-051835

7. Walker LM, Cedeño-Sanchez M, Carbonero F et al (2019) The response of litter-associated Myxomycetes to long-term nutrient addition in a lowland tropical forest. J Eukaryot Microbiol 66:757-770. https://doi.org/10.1111/jeu.12724

8. Bahram M, Hildebrand F, Forslund SK et al (2018) Structure and function of the global topsoil microbiome. Nature. https://doi.org/ 10.1038/s41586-018-0386-6

9. Tedersoo L, Bahram M, Põlme S et al (2014) Global diversity and geography of soil fungi. Science. https://doi.org/10.1126/science. 1256688

10. Grossart HP, Van den Wyngaert S, Kagami M et al (2019) Fungi in aquatic ecosystems. Nat Rev Microbiol 17:339-354

11. Amend A, Burgaud G, Cunliffe M, et al (2019) Fungi in the marine environment: open questions and unsolved problems. mBio 10 
12. Zanne AE, Abarenkov K, Afkhami ME et al (2020) Fungal functional ecology: bringing a trait-based approach to plant-associated fungi. Biol Rev 95:409-433. https://doi.org/10.1111/brv.12570

13. Trouvelot S, Bonneau L, Redecker D, et al (2015) Arbuscular mycorrhiza symbiosis in viticulture: a review. Agron Sustain Dev

14. Teste FP, Jones MD, Dickie IA (2020) Dual-mycorrhizal plants: their ecology and relevance. New Phytol 225:1835-1851

15. Kokkoris V, Lekberg Y, Antunes PM, et al (2020) Codependency between plant and arbuscular mycorrhizal fungal communities: what is the evidence? New Phytol

16. Hoeksema JD, Averill C, Bhatnagar JM et al (2020) Ectomycorrhizal plant-fungal co-invasions as natural experiments for connecting plant and fungal traits to their ecosystem consequences. Front Forests Glob Change. https://doi.org/10.3389/ffgc.2020. 00084

17. Biedermann PHW, Vega FE (2020) Ecology and evolution of insect-fungus mutualisms. Annu Rev Entomol 65:431-455

18. de Bekker C, Ohm RA, Loreto RG et al (2015) Gene expression during zombie ant biting behavior reflects the complexity underlying fungal parasitic behavioral manipulation. BMC Genomics. https://doi.org/10.1186/s12864-015-1812-x

19. Lavefve L, Marasini D, Carbonero F (2019) Microbial ecology of fermented vegetables and non-alcoholic drinks and current knowledge on their impact on human health. In: Advances in food and nutrition research. Academic Press Inc., pp 147-185

20. Raymond Eder ML, Reynoso C, Lauret SC, Rosa AL (2017) Isolation and identification of the indigenous yeast population during spontaneous fermentation of Isabella (Vitis labrusca L.) grape must. Front Microbiol. https://doi.org/10.3389/fmicb.2017.00532

21. Mendoza LM, Vega-Lopez GA, Fernández de Ullivarri M, Raya RR (2019) Population and oenological characteristics of non-Saccharomyces yeasts associated with grapes of Northwestern Argentina. Arch Microbiol. https://doi.org/10.1007/s00203-018-1601-4

22. Padilla B, Gil J V., Manzanares P (2016) Past and future of nonSaccharomyces yeasts: from spoilage microorganisms to biotechnological tools for improving wine aroma complexity. Front Microbiol

23. Cureau N, Threlfall R, Carbonero F et al (2021) Fungal diversity and dynamics during grape wine fermentations with different sulfite levels and yeast inoculations. Am J Enol Vitic. https://doi. org/10.5344/ajev.2021.20054

24. Saikkonen K, Nissinen R, Helander M (2020) Toward comprehensive plant microbiome research. Front Ecol Evol. https://doi. org/10.3389/fevo.2020.00061

25. Vannette RL (2020) The floral microbiome: plant, pollinator, and microbial perspectives. Annu Rev Ecol Evol Syst. https://doi.org/ 10.1146/annurev-ecolsys-011720-013401

26. Veloso TGR, da Silva M, de CS, Cardoso WS, et al (2020) Effects of environmental factors on microbiota of fruits and soil of Coffea arabica in Brazil. Sci Rep. https://doi.org/10.1038/ s41598-020-71309-y

27. Unterseher M, Siddique AB, Brachmann A, Peršoh D (2016) Diversity and composition of the leaf mycobiome of beech (Fagus sylvatica) are affected by local habitat conditions and leaf biochemistry. PLoS ONE. https://doi.org/10.1371/journal.pone. 0152878

28. Del Frari G, Gobbi A, Aggerbeck MR et al (2019) Characterization of the wood mycobiome of Vitis vinifera in a vineyard affected by esca Spatial distribution of fungal communities and their putative relation with leaf symptoms. Front Plant Sci. https:// doi.org/10.3389/fpls.2019.00910

29. Rodriguez PA, Rothballer M, Chowdhury SP, et al (2019) Systems biology of plant-microbiome interactions. Molecular Plant

30. Gianoulis TA, Griffin MA, Spakowicz DJ et al (2012) Genomic analysis of the hydrocarbon-producing, cellulolytic, endophytic fungus Ascocoryne sarcoides. PLoS Genet. https://doi.org/10. 1371/journal.pgen. 1002558

31. Strobel GA (2014) Methods of discovery and techniques to study endophytic fungi producing fuel-related hydrocarbons. Natural Product Reports

32. Booth E, Strobel G, Knighton B et al (2011) A rapid column technique for trapping and collecting of volatile fungal hydrocarbons and hydrocarbon derivatives. Biotech Lett. https://doi.org/ 10.1007/s10529-011-0660-2

33. Saxena S, Strobel GA (2020) Marvellous Muscodor spp.: update on their biology and applications. Microb Ecol 82(1). https://doi. org/10.1007/s00248-020-01644-0

34. Oita S, Carey J, Kline I, et al (2021) Methodological approaches frame insights into endophyte richness and community composition. Microb Ecol 82(1). https://doi.org/10.1007/ s00248-020-01654-y

35. Bao G, Song M, Wang Y, et al (2020) Does Epichloë endophyte enhance host tolerance to root hemiparasite? Microb Ecol 82(1). https://doi.org/10.1007/s00248-020-01496-8

36. Xie XG, Zhao YY, Yang Y, et al (2020) Endophytic fungus alleviates soil sickness in peanut crops by improving the carbon metabolism and rhizosphere bacterial diversity. Microb Ecol 82(1). https://doi.org/10.1007/s00248-020-01555-0

37. Win PM, Matsumura E, Fukuda K (2021) Effects of pesticides on the diversity of endophytic fungi in tea plants. Microb Ecol 82(1). https://doi.org/10.1007/s00248-020-01675-7

38. Cureau N, Threlfall R, Savin M, et al (2021) Year, location, and variety impact on grape-, soil-, and leaf-associated fungal microbiota of Arkansas-grown table grapes. Microb Ecol 82(1). https:// doi.org/10.1007/s00248-021-01698-8

39. Shi YW, Yang HM, Chu M, et al (2021) Diversity and spatiotemporal dynamics of fungal communities in the rhizosphere soil of cotton in the arid region of Northwest China. Microb Ecol 82(1). https://doi.org/10.1007/s00248-020-01646-y

40. Ferreira DA, da Silva TF, Pylro VS, et al (2020) Soil microbial diversity affects the plant-root colonization by arbuscular mycorrhizal fungi. Microb Ecol 82(1). https://doi.org/10.1007/ s00248-020-01502-z

41. dos Passos JH, Maia LC, de Assis DMA, et al (2020) Arbuscular mycorrhizal fungal community structure in the rhizosphere of three plant species of crystalline and sedimentary areas in the Brazilian dry forest. Microb Ecol 82(1). https://doi.org/10.1007/ s00248-020-01557-y

42. Rodrigues LA, da Silva DKA, Yano-Melo AM (2021) Arbuscular mycorrhizal fungal assemblages in conservation unit of Atlantic forest areas under native vegetation and natural regeneration. Microb Ecol 82(1). https://doi.org/10.1007/s00248-020-01653-Z

43. Kellogg JA, Reganold JP, Murphy KM, Carpenter-Boggs LA (2021) A plant-fungus bioassay supports the classification of quinoa (Chenopodium quinoa Willd.) as inconsistently mycorrhizal. Microb Ecol 82(1). https://doi.org/10.1007/s00248-021-01710-1

44. Romero-Olivares AL, Morrison EW, Pringle A, Frey SD (2021) Linking genes to traits in fungi. Microb Ecol 82(1). https://doi. org/10.1007/s00248-021-01687-x

45. Ogaki MB, Pinto OHB, Vieira R, et al (2021) Fungi present in Antarctic deep-sea sediments assessed using DNA metabarcoding. Microb Ecol 82(1). https://doi.org/10.1007/s00248-020-01658-8

46. Rosa LH, Pinto OHB, Convey P, et al (2020) DNA metabarcoding to assess the diversity of airborne fungi present over Keller Peninsula, King George Island, Antarctica. Microb Ecol 82(1). https://doi.org/10.1007/s00248-020-01627-1

47. Pino-Bodas R, Stenroos S (2020) Global biodiversity patterns of the photobionts associated with the genus Cladonia (Lecanorales, Ascomycota). Microb Ecol 82(1). https://doi.org/10.1007/ s00248-020-01633-3 
48. Morrison ES, Thomas P, Ogram A, et al (2020) Characterization of bacterial and fungal communities reveals novel consortia in tropical oligotrophic peatlands. Microb Ecol 82(1). https://doi. org/10.1007/s00248-020-01483-Z

49. Huang M, Chai L, Jiang D, et al (2020) Spatial patterns of soil fungal communities are driven by dissolved organic matter
(DOM) quality in semi-arid regions. Microb Ecol 82(1). https:// doi.org/10.1007/s00248-020-01509-6

50. Borruso L, Checcucci A, Torti V, et al (2021) I like the way you eat it: lemur (Indri indri) gut mycobiome and geophagy. Microb Ecol 82(1). https://doi.org/10.1007/s00248-020-01677-5 